\title{
PERMASALAHAN GURU SEKOLAH DASAR SELAMA PEMBELAJARAN DARING
}

\section{PROBLEMS FACED BY TEACHERS IN ELEMENTARY SCHOOL DURING ONLINE LEARNING}

\author{
Dessy Dwitalia Sari \\ Program Studi Pendidikan Guru Sekolah Dasar, Fakultas Keguruan dan Ilmu Pendidikan, \\ Universitas Lambung Mangkurat, Indonesia \\ e-mail: dessy.sari@ulm.ac.id
}

\begin{abstract}
ABSTRAK
Tujuan dalam penelitian ini adalah menemukan permasalahan yang muncul pada saat melaksanakan pembelajaran daring selama masa pandemi Covid-19. Jenis penelitian yang digunakan adalah penelitian kualitatif deskriptif. Pengumpulan data dilakukan dengan pengisian angket dan wawancara secara daring. Sumber data penelitian adalah 60 guru sekolah dasar yang tersebar di Provinsi Kalimantan Selatan. Tahap-tahap analisis data yang dilakukan adalah reduksi data, penyajian data, verifikasi data, dan penarikan simpulan. Temuan penelitan ini adalah bahwa permasalahan yang sering dihadapi guru sekolah dasar pada pembelajaran daring yaitu: 1) sebanyak 60\% peserta didik masih terkendala ketersediaan gawai dan kesulitan akses jaringan; 2) pengunaan aplikasi daring yang masih monoton, sebanyak 50\% pembelajaran lebih banyak menggunakan whatsapp; 3) sebanyak $90 \%$ guru masih mengalami kesulitan dalam evaluasi pembelajaran daring, dan 4) sebanyak 47\% orang tua masih jarang mendampingi peserta didik belajar dari rumah. Saran-saran yang dapat dituliskan yaitu perlu adanya beberapa hal yang dapat mendukung pembelajaran daring, diantaranya: 1) aplikasi untuk pembelajaran daring yang mudah penggunaannya dan dapat diakses secara offline; 2) pendampingan dari orang tua untuk dapat menunjang keberhasilan belajar; 3) kerjasama dengan orang tua dalam hal evaluasi pembelajaran daring.
\end{abstract}

Kata kunci: Pembelajaran daring, covid-19, guru SD

\begin{abstract}
This study aims to find emerging problems in online learning during Covid-19 pandemic. Qualitative descriptive research type is used in this study. Online questionnaire and interview were conducted in data collection. The subjects of this study are 60 teachers in South Borneo Province. Steps in data analysis conducted are data reduction, data presentation, data verification, and conclusion formulation. Research findings obtained regarding problems faced by teachers in elementary school during online teaching are: 1) 60\% of students have problems in having device and internet connection network; 2) $50 \%$ of teaching is implemented by using Whatsapp, resulting monotonous online application usage; 3) $90 \%$ of teachers have difficulty in evaluating online learning results; and 4) 47\% of parents seldom guide their children during online learning. These problems need recommendations supporting online learning as follows: 1) online learning application that is easy to use and can be offline accessed; 2) parents' guidance can support the success of learning; 3) teamwork of teachers and parents in evaluating online learning is required.
\end{abstract}

Keywords: Online Learning, Covind-19, Elementary School Teachers 


\section{PENDAHULUAN}

Pandemi covid-19 berdampak besar pada bangsa ini. Hampir semua bidang terkena imbas covid-19, termasuk pada bidang pendidikan. Terhitung sejak Maret 2020, organisasi kesehatan dunia (WHO) menetapkan covid-19 sebagai pandemi yang telah melanda lebih dari 200 negara di dunia [1]. Pemerintah Indonesia melakukan beberapa tindakan untuk menekan penyebaran virus covid-19 di Indonesia. Kebijakan lockdown atau karantina menjadi salah satu tindakan untuk meminimalisasi menyebarnya virus covid-19. Kegiatan belajar-mengajar menjadi satu dari banyak aktivitas yang terdampak virus covid-19. Selama pandemi virus covid-19, kegiatan belajar-mengajar dilaksanakan dari rumah.

Pembelajaran dalam jaringan (daring) merupakan alternatif yang dapat ditempuh dalam kegiatan belajar-mengajar selama pandemi covid-19. Pembelajaran tidak lagi dilakukan secara tatap muka, tetapi menggunakan berbagai aplikasi baik yang sinkron maupun asinkron. Kegiatan pembelajaran ini diperkuat dalam surat edaran, yang menyebutkan bahwa kesehatan dan keselamatan peserta didik, pendidik, tenaga kependidikan, keluarga, dan masyarakat merupakan prioritas utama dalam menetapkan kebijakan pembelajaran" [2]. Pembelajaran daring meminimalisasi kerumunan yang mungkin akan terjadi selama proses pembelajaran di sekolah.

Berdasarkan surat edaran tersebut, semua lembaga pendidikan mengambil langkah cepat sebagai respons antisipasi penyebaran covid-19 dan pelaksanaan pembelajaran. Sekolah Dasar merupakan salah satu jenjang pendidikan yang merasakan dampak dari pandemi covid19. Sekolah dan pihak sekolah mulai mengubah strategi pembelajaran yang awalnya merupakan tatap muka diubah menjadi pembelajaran non-tatap muka atau pembelajaran online dan atau pembelajaran jarak jauh (PJJ). Pada prinsipnya, terdapat model pembelajaran lain yang dapat digunakan oleh guru, yaitu kombinasi tatap muka dan daring [3]. Akan tetapi, memaksakan tatap muka pada era pandemi covid-19 bukan hal yang bijak.

Sementara itu, metode pembelajaran daring tidak menuntut peserta didik untuk hadir di kelas. Peserta didik dapat mengakses pembelajaran melalui media internet. Pembelajaran daring merupakan cara baru dalam menerapkan proses pembelajaran yang memanfaatkan gawai dalam menyampaikan materi pembelajaran. Pembelajaran daring berpangku sepenuhnya pada keberadaan internet, sinyal, dan kuota atau data akses internet. Pembelajaran daring merupakan bentuk penyampaian pembelajaran konvensional yang dilaksanakan melalui internet atau secara digital [4]. Pembelajaran daring dirasa efektif dalam menyampaikan materi dari guru kepada peserta didik pada masa pandemi covid-19.

Berbagai model, strategi dan media digunakan oleh guru dalam rangka menyampaikan materi secara maksimal kepada peserta didik meski tidak dilakukan secara tatap muka. Media pembelajaran online atau sering disebut dengan e-learning merupakan media penunjang pendidikan yang menempatkan guru sebagai fasilitator [5]. Oleh sebab itu, guru dituntut untuk menciptakan teknik mengajar yang baik, menyajikan bahan ajar yang menarik, sementara peserta didik dituntut untuk berpartisipasi secara aktif dalam proses belajar. Pemerintah menyediakan berbagai aplikasi pembelajaran yang dapat diakses dan digunakan oleh guru dan peserta didik. Pemanfaatan sistem pembelajaran daring merupakan salah satu upaya yang dapat dilakukan untuk mengatasi permasalahan dan memudahkan peserta didik mengakses materi pembelajaran. Selain media, saling berkomunikasi dan berdiskusi secara online adalah hal yang dapat dilakukan selama pembelajaran daring [6].

Pembelajaran online dianggap sulit bagi guru sekolah dasar yang terbiasa melakukan pembelajaran melalui tatap muka. Perubahan yang terjadi secara cepat dan mendadak menjadi alasan ketidaksiapan guru dalam menyajikan pembelajaran secara daring. Semua guru tidak pandang usia, jabatan dan pengalaman dipaksa untuk lebih melek teknologi. Sejauh ini belum ada evaluasi secara khusus yang dilakukan selama terhadap pembelajaran daring, selain itu pembelajaran daring juga dilakukan melalui bimbingan orang tua [7]. Peran orang tua menjadi sangat penting dalam mendampingi anaknya selama belajar di rumah. 
Penelitian ini dilakukan di Kalimantan Selatan yang juga mengalami dampak pandemi covid-19. Penelitian dilaksanakan dengan mendeskripsikan pembelajaran daring yang dilaksanakan di sekolah dasar. Hambatan-hambatan pelaksanaan pembelajaran daring dikaji guna memperoleh solusi demi kelancaraan pembelajaran daring di sekolah dasar. Oleh karena itu, perlu dilakukan penelitian mengenai permasalahan yang muncul pada saat pembelajaran daring di dekolah dasar khususnya di Provinsi Kalimantan Selatan.

\section{METODE PENELITIAN}

Penelitian ini merupakan penelitian deskriptif kualitatif untuk menemukan permasalahan yang ditemukan pada saat pembelajaran daring. Pengumpulan data dilakukan secara survei yang dilaksanakan online. Populasi penelitian adalah guru sekolah dasar yang tersebar di Kalimantan Selatan. Sumber data penelitian sebanyak 60 orang guru dari berbagai SD di Kalimantan Selatan. Pengumpulan data dilakukan dengan wawancara dan pengisian angket secara daring. Wawancara yang dilakukan melalui telepon selular dan chat melalui sosial media.

Teknik penentuan sumber data penelitian yang digunakan sample random sampling yang artinya setiap anggota populasi memiliki peluang yang sama untuk menjadi sampel penelitian. Pengumpulan data primer dilakukan dengan menyebar kuisioner secara daring kepada 60 responden guru sekolah dasar. Responden ialah guru sekolah dasar yang berada pada rentang usia lebih dari 30 tahun. Jenis kelamin responden 87\% wanita dan 13\% laki-laki. Semua responden memiliki latar belakang pendidikan sarjana.

Responden merupakan guru sekolah dasar yang berdomisili di wilayah Kotabaru, Balangan, Tanjung, Banjarmasin, Barito Kuala, Marabahan, Kabupaten Banjar, Balangan Tanah Laut, Tanah Bumbu, Tapin, Tanah Bumbu, Hulu Sungai Utara dan Hulu Sungai Selatan. Sebaran responden adalah guru kelas 1 sampai dengan kelas 6. Data diperoleh melalui pengisian pertanyaan-pertanyaan yang dibagikan kepada seluruh responden dalam bentuk Google Form. Selanjutnya data yang terkumpul dianalisis untuk dideskripsi. Teknik analisis data dilakukan dengan cara reduksi data, penyajian data, dan penarikan kesimpulan.

\section{HASIL DAN PEMBAHASAN}

\section{Hasil Penelitian}

Pelaksanaan pembelajaran daring menjadi hal baru bagi pendidik di Indonesia. Pembelajaran yang terlihat mudah ini pada kenyataannya lebih membutuhkan banyak persiapan agar materi yang disampaikan kepada peserta didik secara efektif. Media gawai, gadget, laptop, maupun internet menjadi yang utama demi tercapainya pembelajaran daring. Faktanya pada awal pembelajaran daring dimulai banyak pemasalahan dan kendala yang dihadapi serta dirasakan oleh guru dan peserta didik.

\section{Gawai dan Jaringan Internet}

Keberadaan gawai menjadi faktor utama dalam pelaksanaan pembelajaran daring. Pembelajaran daring tidak akan terlaksana jika guru dan peserta didik tidak memiliki smartphone atau komputer/ laptop. Permasalahan yang ditemukan adalah masih terdapat peserta didik yang melakukan pembelajaran dengan ikut serta pada smartphone temannya karena orang tuanya tidak memiliki telepon pintar. Kondisi di lapangan memperlihatkan masih terdapat banyak peserta didik yang orang tuanya tidak memiliki telepon pintar atau smartphone. 


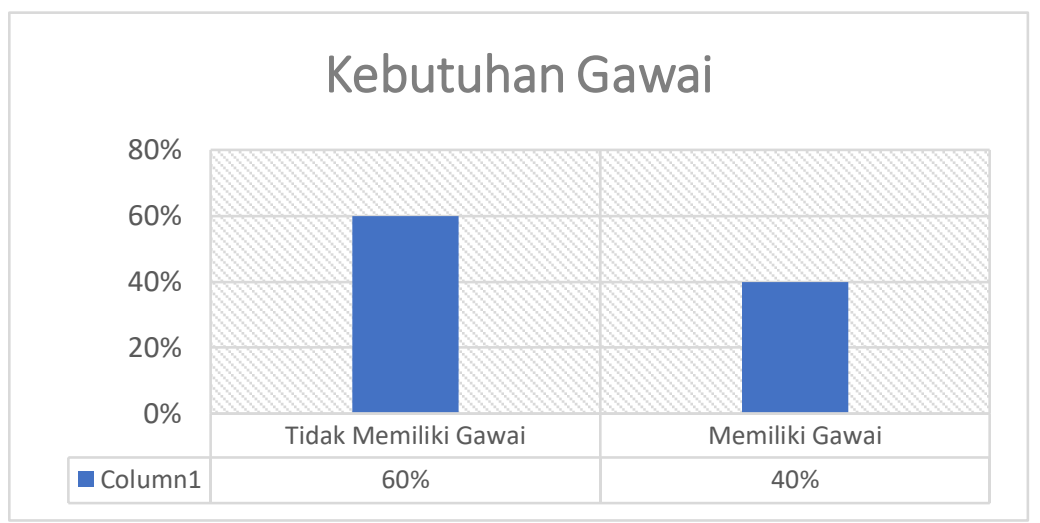

Gambar 1. Kebutuhan Gawai Peserta Didik

Berdasarkan Gambar 1 dapat diketahui bahwa sebanyak 60\% peserta didik di sekolah dasar yang belum memiliki gawai, sementara $40 \%$ lainnya sudah memiliki gawai meski harus berbarengan dengan anggota keluarga lainnya. Guna menyiasati kendala yang dihadapi peserta didik, guru melakukan kunjungan belajar ke rumah peserta didik dengan membuat kelompok belajar. Pelaksanaan pembelajaran yang menerapkan kunjungan ke rumah peserta didik dilakukan dengan tetap melakukan protokol kesehatan yang telah dianjurkan oleh pemerintah.

Selain itu, kebutuhan jaringan internet dan kuota data internet juga merupakan permasalahan yang dihadapi guru dan peserta didik. Banyaknya pembelajaran daring yang dilakukan dengan menggunakan video membutuhkan akses jaringan yang besar dan cepat. Minimnya akses jaringan internet menjadi keluhan guru dan orang tua, terutama mereka yang tinggal di daerah pegunungan dan pesisir pantai. Kendala jaringan menjadi permasalahan yang utama pada pembelajaran daring di Provinsi Kalimantan Selatan.

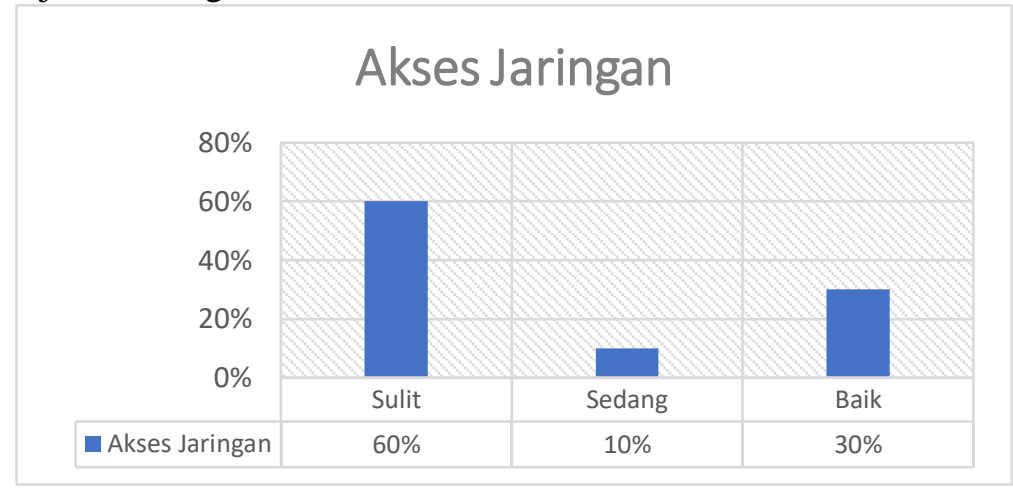

Gambar 2. Akses Jaringan

Berdasarkan data pada Gambar 2 dapat diketahui bahwa 60\% daerah termasuk dalam katagori sulit jaringan, $10 \%$ daerah termasuk dalam kategori sedang, dan 30\% daerah termasuk dalam kategori baik untuk akses jaringan. Sulitnya akses jaringan yang ada di daerah menjadikan materi yang disampaikan oleh guru juga terhambat. Penggunaan obrolan atau menyampaikan materi melalui chat (kecuali video) pada aplikasi whatsapp menjadi salah satu solusi untuk mengatasi lemahnya jaringan internet. Selain itu juga guru meminta orang tua peserta didik datang ke sekolah untuk mengambil tugas untuk peserta didik. Pemerintah juga memberikan solusi berupa tanyang edukatif yang dapat dilihat ditelevisi pada jam tertentu, hal ini membantu peserta didik yang tidak memiliki gawai atau jaringan internetnya sulit.

\section{Aplikasi Pembelajaran}

Pelaksanaan pembelajaran daring memaksa guru untuk lebih banyak mengenal internet dan teknologi sebagai satu-satunya sarana pembelajaran dengan peserta didik. Pembelajaran daring yang dilakukan dapat menggunakan berbagai aplikasi. Hanya saja banyak 
ditemui guru yang belum mampu menggunakan aplikasi daring yang ada. Beberapa orang tua juga mengalami kendala menggunakan aplikasi yang digunakan.

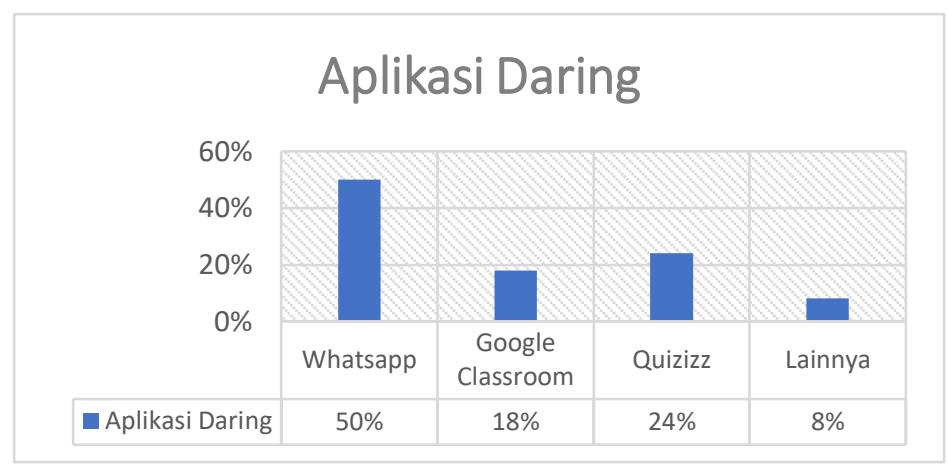

Gambar 3. Aplikasi Daring

Berdasarkan data pada Gambar 3, aplikasi daring yang paling banyak digunakan adalah whatsapp, yaitu sebanyak $50 \%$, diikuti quizziz sebanyak $24 \%$, google classroom sebanyak $18 \%$, dan aplikasi lainnya sebanyak $8 \%$. Guru lebih sering menggunakan whatsapp karena kemudahan penggunaannya, khususnya dalam pembelajaran daring. Melalui whatsapp guru membentuk grup dengan orang tua dan peserta didik untuk memberikan materi, tugas, dan informasi sekolah kepada wali peserta didik. Beberapa guru lain menggunakan aplikasi Google Classroom, Quizizz, dan Zoom dalam proses pembelajaran. Pemerintah juga menyediakan portal belajar yang diberi nama Rumah Belajar sebagai sarana pembelajaran daring.

\section{Evaluasi Pembelajaran}

Pembelajaran daring yang dilakukan selama masa pandemi Covid-19 ini memaksa guru, orang tua dan peserta didik bekerja dan belajar lebih dari biasanya. Pembelajaran yang dilakukan secara daring juga mengubah teknik penilaian oleh guru. Kegiatan penilaian ini sangat penting dan menjadi bagian dalam proses belajar mengajar. Penilaian dilakukan untuk mendapatkan informasi tentang pencapaian kompetensi peserta didik pada suatu materi pembelajaran.

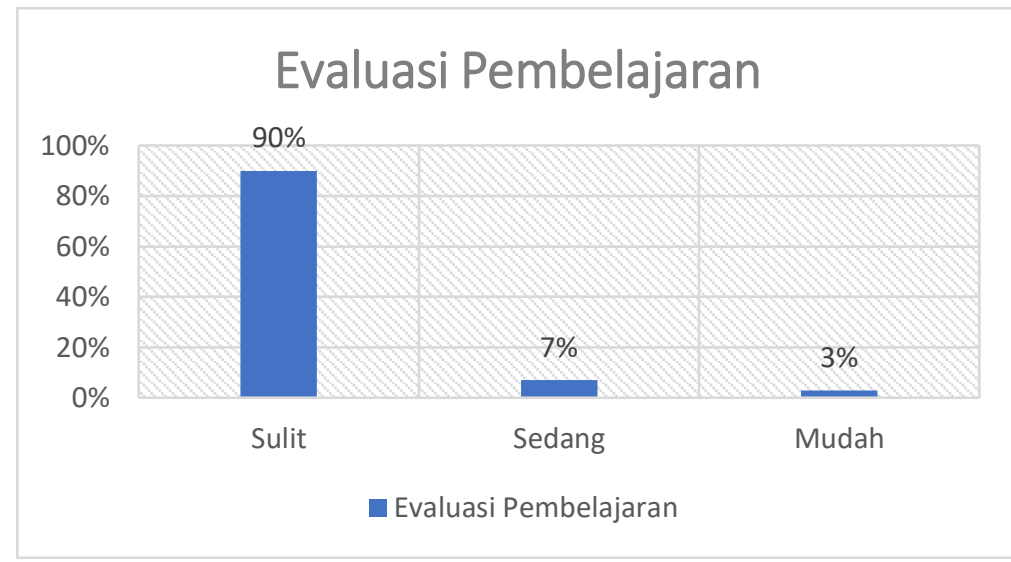

Gambar 4. Evaluasi Pembelajaran

Berdasarkan data pada Gambar 4 dapat diketahui bahwa sebanyak 90\% guru mengalami kesulitan dalam mengevaluasi pembelajaran daring, 7\% mengatakan sedang, dan 3\% mengatakan mudah. Penilaian yang dilakukan pada pembelajaran daring masih sama dengan pembelajaran tatap muka. Guru memberikan penilaian pada aspek kognitif, afektf, psikomotor.

Pada aspek kognitif guru dapat melihat dari hasil tugas yang dikerjakan oleh peserta didik, baik yang dilakukan melalui aplikasi atau tugas yang dikumpulkan di sekolah melalu orang tua peserta didik. Kendala yang dihadapi guru adalah meningkatnya nilai kognitif pada semua peserta didik. Hal ini menjadi keraguan guru dalam memberikan penilaian. Soal yang 
diberikan kepada peserta didik apakah benar-benar dikerjakan secara mandiri atau dengan bantuan orang tua atau orang dewasa di sekitar peserta didik. Pada aspek afektif dan psikomotorik guru juga mengalami kendala dikarenakan tidak dapat mengamati secara langsung kegiatan yang dilakukan peserta didik di rumah.

\section{Pendampingan Orang Tua}

Pelaksanaan pembelajaran daring dapat berjalan dengan efektif apabila peserta didik memperoleh pendampingan dan pengawasan yang maksimal dari orang tua. Pada awal pembelajaran daring dilaksanakan hampir $90 \%$ orang tua memberikan pengawasan kepada anaknya, dikarenakan banyaknya orang tua bekerja yang diliburkan atau bahkan dirumahkan.

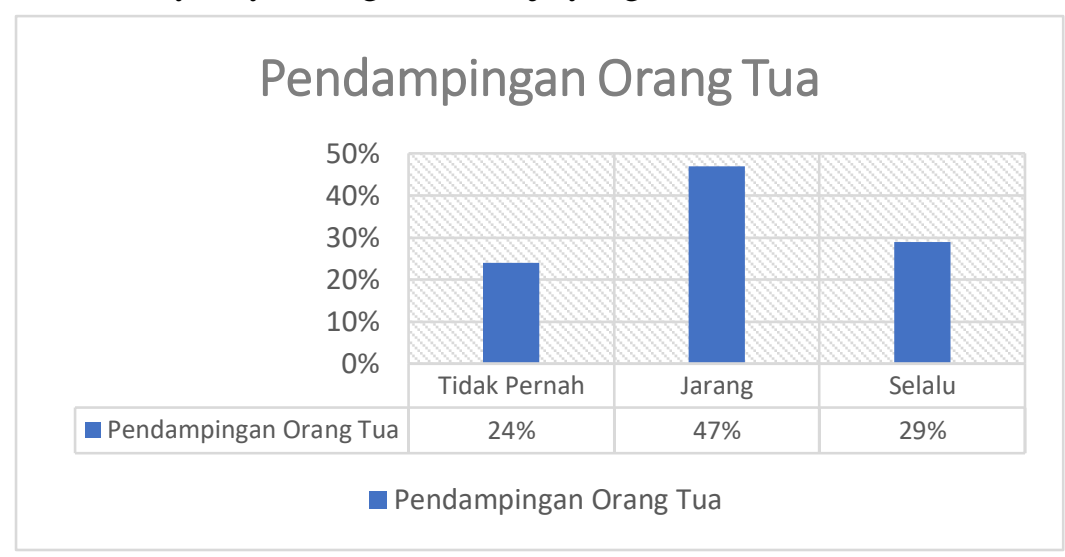

Gambar 5. Pendampingan Orang Tua

Berdasarkan data pada Gambar 5 dapat diketahui bahwa sekitar $47 \%$ orang tua jarang mendampingi peserta didik belajar, 24\% tidak pernah, dan 29\% selalu mendampingi peserta didik belajar dari rumah. Fakta dilapangan menunjukkan bahwa makin lama pembelajaran daring yang dilakukan makin berkurang pendampingan dan pengawasan orang tua terhadap kegiatan belajar anaknya. Hal ini dikarenakan banyaknya orang tua yang harus kembali bekerja, mengurus rumah, dan membagi waktu dengan mengawasi anak belajar. Kebanyakan orang tua yang bekerja tidak mengawasi anaknya pada saat pembelajaran daring, dikarenakan anak melakukan belajar dari rumah dan orang tua bekerja diluar rumah (kantor, sawah, laut, dan sebagainya).

Orang tua mempercayakan penuh kegiatan belajar daring kepada anak mereka. Kenyataannya banyak orang tua yang lebih senang mengambil soal atau tugas di sekolah dan menyuruh anaknya mengerjakan dibandingkan dengan melakukan pembelajaran daring. Orang tua merasa jika anak mereka sudah mengejakan tugas dari guru, kegiatan belajar yang dilakukan sudah selesai.

\section{Pembahasan}

Gawai dan Jaringan Internet

Berdasarkan hasil penelitian yang telah dilaksanakan, ditemukan bahwa lebih dari separuh peserta didik yaitu sebanyak $60 \%$ tidak memiliki gawai yang dapat digunakan sebagai sarana dalam pembelajaran daring. Sementara itu $40 \%$ lainnya memiliki meski harus berbagi dengan anggota keluarga lainnya. Gawai termasuk salah satu bentuk teknologi yang dapat digunakan dalam pembelajaran selama pandemi covid-19. Pembelajaran yang mengimlementasikan teknologi, dapat meningkatkan hasil belajar peserta didik [8]. Oleh sebab itu, keberadaan gawai harus dapat dimanfaatkan secara optimal oleh guru agar dapat memaksimalkan kegiatan belajar mengajar selama pandemi ini.

Gawai yang dibutuhkan dalam pembelajaran selama pandemic covid-19 adalah model smartphone. Gawai model ini adalah gawai yang dimiliki oleh sebagian besar peserta didik. Akan tetapi, keberadaan sarana gawai yang dimiliki peserta didik tidak didukung dengan 
jaringan yang memadai. Hal ini didukung dari hasil penelitian yang telah dilakukan, bahwa sebanyak 60\% subjek mengalami kesulitan akses jaringan, 30\% akses jaringan dalam katagori sedang, dan $10 \%$ akses jaringan dalam katagori baik. Hal ini berarti, hampir separuh lebih yang mengalami permasalahan dalam akses jaringan.

Padahal, jaringan internet yang dapat menghubungkan guru dan peserta didik, sehingga proses belajar mengajar dapat berjalan dengan baik meskipun ditengah pandemi covid19 [9]. Dengan demikian, keberadaan jaringan internet yang stabil akan menjadi kunci keberhasilan pembelajaran selama masa pandemi.

\section{Aplikasi Pembelajaran}

Aplikasi pembelajaran yang digunakan selama pandemi covid-19 cukup bervariasi. Data hasil penelitian menunjukkan aplikasi daring yang paling banyak digunakan adalah whatsapp, yaitu sebanyak 50\%, diikuti quizziz sebanyak $24 \%$, google classroom sebanyak $18 \%$, dan aplikasi lainnya sebanyak $8 \%$.

Pengunaan whatsapp memang cukup mudah, sehingga memudahkan interaksi antara guru dan peserta didik. Interaksi yang baik, selama proses pembelajaran berlangung akan mengantarkan peserta didik mendapatkan hasil belajar yang optimal [10]. Whatsapp juga mendukung penggunanya untuk berkirim gambar, video, bahkan suara, sehingga dapat mendukung kegiatan belajar mengajar selama pandemi covid-19.

\section{Evaluasi Pembelajaran}

Kegiatan pembelajaran tentu memerlukan evaluasi, untuk dapat mengetahui ketercapaian hasil belajar. Data hasil penelitian menunjukkan bahwa sebanyak $90 \%$ guru mengalami kesulitan dalam mengevaluasi pembelajaran daring, 7\% mengatakan sedang, dan 3\% mengatakan mudah. Kesulitan proses evaluasi terjadi karena guru tidak melihat secara langsung dalam melakukan kegiatan evaluasi. Sementara itu, evaluasi hasil belajar harus dilakukan secara menyeluruh dari berbagai aspek yang meliputi kognitif, afektif, dan psikomotor.

Penilaian ranah kognitif, biasanya akan diambil dari tugas yang diberikan baik individu maupun kelompok, serta berbagai ujian yang harus diikuti peserta didik. Sementara itu, penilaian sikap diambil berdasarkan aktivitas yang dilakukan oleh peserta didik sehari-hari selama proses pembelajaran [11]. Selama penilaian sikap ini, guru tidak dapat melakukan penilaian secara langsung. Oleh sebab itu, dibutuhkan kerja sama yang baik antara guru dan orang tua agar dapat memberikan penilaian sesuai dengan perkembangan peserta didik.

\section{Pendampingan Orang Tua}

.Keberhasilan pendidikan dapat terwujud karena adanya kerjasama yang baik antara sekolah, orangtua, dan masyarakat. Data hasil penelitian menunjukkan sebanyak $47 \%$ orang tua mengaku jarang mendampingi peserta didik belajar, 24\% tidak pernah, dan $29 \%$ selalu mendampingi peserta didik belajar dari rumah. Padahal, selama belajar dari rumah, orang tua perlu mendampingi peserta didik agar memperoleh hasil belajar yang optimal.

Dukungan dari orang tua, termasuk dalam hal pendampingan peserta didik saat belajar dari rumah, berperan dalam menentukan keberhasilan pendidikan [12]. Disisi lain, pelaksanaan kegiatan pembelajaran juga dipengaruhi dari proses interaksi peserta didik dengan orang-orang sekitarnya, termasuk orang tua [13]. Dengan demikian, proses pendampingan dan interaksi antara orang tua dan peserta didik sangat diperlukan dalam kegiatan belajar dari rumah, meskipun kendali kegiatan pembelajaran tetap dilakukan oleh guru. 


\section{SIMPULAN}

Permasalahan yang dihadapi pada saat pembelajaran daring adalah unculnya banyak kendala dan respons baik dari guru, orang tua, dan peserta didik menjadi topik yang harus dicarikan solusinya. Meski berada pada kondisi yang terbatas, pembelajaran daring harus tetap dilaksanakan. Hambatan yang muncul ketika pembelajaran daring yaitu :1) Dilihat dari sarana dan prasarana, sebanyak $60 \%$ peserta didik tidak memiliki gawai, $40 \%$ lainnya memiliki gawai meski harus berbagi dengan anggota keluarga lain. Sementara itu, terkait akses jaringan, sebanyak 60\% mengaku kesulitan akses jaringan, 30\% mengaku akses jaringan dalam kataori sedang, da $10 \%$ mengaku tidak memiliki akses jaringan. 2) Dilihat dari penggunan aplikasi daring sebanyak 50\% menggunakan whatsapp, 24\% menggunakan quizziz, $18 \%$ menggunakan google classroom, dan $8 \%$ menggunakan aplikasi lainnya. 3) Dilihat dari evaluasi pembelajaran daring, sebanyak 90\% guru mengalami kesulitan dalam mengevaluasi pembelajaran daring, $7 \%$ mengatakan sedang, dan 3\% mengatakan mudah dalam melakukan kegiatan evaluasi. 4) Dilihat dari peran orang tua dalam mendampingi peserta didik belajar dari rumah $24 \%$ mengaku tidak pernah mendampingi, 47\% mengaku jarang mendampingi, dan $29 \%$ selalu mendampingi peserta didik belajar dari rumah.

Mencermati simulan hasil penelitian, maka dapat dituliskan beberapa saran untuk pembelajaran daring. Adapun saran-saran yang dapat dituliskan yaitu 1) perlu adanya aplikasi untuk pembelajaran daring yang mudah penggunaannya dan dapat diakses secara offline; 2) perlu adanya pendampingan dari orang tua untuk dapat menunjang keberhasilan belajar; 3) perlu adanya kerjasama dengan orang tua dalam hal evaluasi pembelajaran daring.

\section{DAFTAR PUSTAKA}

[1] C. Sohrabi et al., "World Health Organization declares global emergency: A review of the 2019 novel coronavirus (COVID-19)," International Journal of Surgery, vol. 76, pp. 71-76, 2020, [Online]. Available: https://pubmed.ncbi.nlm.nih.gov/32112977/.

[2] Mendikbud, Surat Edaran Nomor 4 Tahun 2020 Tentang Pelaksanaan Kebijakan Pendidikan dalam Masa Darurat Penyebaran Corona Virus Disease (Covid-19). Indonesia, 2020.

[3] N. H. Zhafira, Y. Ertika, and Chairiyaton, "Persepsi Mahasiswa Terhadap Perkuliahan Daring Sebagai Sarana Pembelajaran Selama Masa Karantina Covid-19," Jurnal Bisnis dan Kajian Strategi Manajemen, vol. 4, no. 1, pp. 37-45, 2020, [Online]. Available: jurnal.utu.ac.id/jbkan/article/view/1981.

[4] K. A. Imania and S. K. Bariah, "Rancangan Pengembangan Instrumen Penilaian Pembelajaran Berbasis Daring," Jurnal Petik, vol. 5, no. 1, pp. 31-47, 2019, [Online]. Available: https://journal.institutpendidikan.ac.id/index.php/petik/article/view/445.

[5] A. Arsyad, Media pembelajaran. Jakarta: Raja Grafindo Persada, 2011.

[6] A. R. Riyanda, K. Herlina, and B. A. Wicaksono, "Evaluasi Implementasi Sistem Pembelajaran Daring Fakultas Keguruan dan Ilmu Pendidikan Universitas Lampung," Jurnal IKRA-ITH Humaniora, vol. 4, no. 1, pp. 66-71, 2020, [Online]. Available: https://journals.upi-yai.ac.id/index.php/ikraith-humaniora/article/view/669.

[7] W. A. F. Dewi, "Dampak COVID-19 terhadap Implementasi Pembelajaran Daring di Sekolah Dasar," Edukatif: Jurnal Ilmu Pendidikan, vol. 2, no. 1, pp. 55-61, 2020, [Online]. Available: https://edukatif.org/index.php/edukatif/article/view/89.

[8] A. Mumpuni and L. Nurpratiwiningsih, "Pengembangan Pembelajaran Berbasis Web untuk Meningkatkan Kemampuan Menulis Kreatif Mahasiswa PGSD," Cakrawala Pendidikan, vol. 37, no. 2, pp. 321-332, 2018, [Online]. Available: https://journal.uny.ac.id/index.php/cp/article/view/20009.

[9] N. B. Argaheni, "Sistematik Review: Dampak Perkuliahan Daring Saat Pandemi COVID-19 Terhadap Mahasiswa Indonesia," PLACENTUM: Jurnal Ilmiah Kesehatan 
dan Aplikasinya, vol. 8, no. 2, p. 99, 2020, [Online]. Available: https://jurnal.uns.ac.id/placentum/article/view/43008.

[10] F. Fembriani, T. R. Koroh, P. Pasmiyati, and R. Polin, "Efektifitas Edmodo Terhadap Hasil Belajar Mahasiswa PGSD Universitas Nusa Cendana," Jurnal Ilmiah KONTEKSTUAL, vol. 2, no. 01, pp. 8-14, 2020, [Online]. Available: http://jurnal.umus.ac.id/index.php/kontekstual/article/view/243.

[11] S. Mardikarini and F. Hamdani, "Pelaksanaan Penilaian Pembelajaran Menggunakan Kurikulum 2013 di SD Negeri 1 Tapak," Jurnal Ilmiah KONTEKSTUAL, vol. 01, no. 1, pp. 70-76, 2019, [Online]. Available: http://jurnal.umus.ac.id/index.php/kontekstual/article/view/61.

[12] T. Andriyani and D. T. Setiyoko, "Makna Pendidikan untuk Peserta Didik yang Ditinggal Ibunya Merantau," Jurnal Ilmiah KONTEKSTUAL, vol. 1, no. 02, pp. 36-42, 2015, [Online].

Available: http://jurnal.umus.ac.id/index.php/kontekstual/article/view/160/96.

[13] D. Sunarsih and Y. Sunarsih, "Persepsi Pendidikan Bagi Bagi Siswa Broken Home (Atudi Kasus SDN Dukuh Payung Jatirokeh)," Jurnal Ilmiah KONTEKSTUAL, vol. 1, no. 02, pp. 1-27, 2015, [Online]. Available: http://jurnal.umus.ac.id/index.php/kontekstual/article/view/61. 